\title{
Original Article \\ Method of Interpreting the High Resolution Seismic Profiles: Principle and Application in Coastal Shallow Water Area of Red River Delta
}

\author{
Tran Nghi ${ }^{1}$, Dinh Xuan Thanh ${ }^{1}$, Tran Thi Thanh Nhan ${ }^{1, *}$, Tran Trong Thinh ${ }^{2}$, \\ Nguyen Thi Phuong Thao ${ }^{1}$, Tran Ngoc Dien ${ }^{1}$, Nguyen Thi Huyen Trang ${ }^{1}$, \\ Pham Nguyen $\mathrm{Ha} \mathrm{Vu}{ }^{1}$, Tran Thi Dung ${ }^{1}$ \\ ${ }^{1}$ VNU University of Science, 334 Nguyen Trai, Thanh Xuan, Hanoi, Vietnam \\ ${ }^{2}$ Marine Geological and Mineral Resources Division, A8/18 Hoang Quoc Viet, Cau Giay Hanoi, Vietnam
}

Received 11 April 2019

Revised 15 May 2019; Accepted 06 June 2019

\begin{abstract}
Establishing a process of interpreting the high-resolution seismic profile according to a sedimentary geological point of view is a very urgent task. The explanation process can be divided into the following steps: (1) Boundary demarcation of sequences based on unconformable surfaces showing signs of erosion of the river bed; (2) Analysis of lithofacies and lithofacies association according to time and to space in relation to global sea level change; (3) Demarcation of systems tract: low stand systems tract (LST), Transgressive systems tract (TST) and Highstand systems tract (HST). On that basis, Tran Nghi (2012) established an integrated general formula between lithofacies and systems tract: (1) $\mathrm{Li}_{\mathrm{LST}}=\operatorname{arLST}+\operatorname{amrLST}$; (2) $\mathrm{Li}_{\mathrm{TST}}=\operatorname{atTST}+\operatorname{amtTST}+\operatorname{mtTST}$; (3) $\mathrm{Li}_{\mathrm{HST}}=\operatorname{ahHST}+\operatorname{amhTST}$

Where, Li - Lithofacies; ar - Alluvial facies of lowstand systems tract; at - Alluvial facies of transgressive systems tract; ah - Deltaic facies of lowstand systems tract; amr - Deltaic facies of highstand systems tract; amt- Coastal facies of transgressive systems tract; mt - Shallow sea facies of maximum transgressive systems tract;

The results have determined the exact location of the ancient river channels and their's change history in the shallow coastal area of the Red River Delta. Before 1787, the ancient Red River channel had the largest scale flowing to the sea through Ha Lan mouth (T22-1), while the river channel flowing into Ba Lat mouth was only a tributary of the Red River (T12). The seismic section of line T22-1 (Ha Lan mouth) allows the determination of the ancient Red River channel and line T12 (Ba Lat mouth) has identified the tributary channel of the Red River. The boundary between lithofacies complexes in vertical seismic section (bottom up) is determined as follows: $\operatorname{arLSTQ}_{1}{ }^{3 \mathrm{~b}}$ $\rightarrow$ atTSTQ $_{2}{ }^{1} \rightarrow$ amt $_{1} \mathrm{TSTQ}_{2}{ }^{1-2} \rightarrow \mathrm{amt}_{2} \mathrm{TSTQ}_{2}{ }^{1-2} \rightarrow \mathrm{mtTSTQ}_{2}{ }^{2} \rightarrow \mathrm{amhHSTQ}_{2}{ }^{3}$.

Keywords: Lithofacies, lithfacies association, seismic wave field, systems tract, transgressive alluvial lithofacies (atTST).
\end{abstract}

\footnotetext{
* Corresponding author:

E-mail address: quynhanthu@gmail.com

https://doi.org/10.25073/2588-1094/vnuees.4380
} 


\title{
Phương pháp minh giải mặt cắt địa chấn nông phân giải cao: Nguyên lý và áp dụng cho vùng biển ven bờ châu thổ sông Hồng
}

\author{
Trần Nghi ${ }^{1}$, Đinh Xuân Thành ${ }^{1}$, Trần Thị Thanh Nhàn ${ }^{1, *}$, Trần Trọng Thịnh ${ }^{2}$, \\ Nguyễn Thị Phương Thảo ${ }^{1}$, Trần Ngọc Diễn ${ }^{1}$, Nguyễn Thị Huyền Trang ${ }^{1}$, \\ Phạm Nguyễn Hà Vũ ${ }^{1}$, Trần Thị Dung ${ }^{1}$, \\ ${ }^{I}$ Truòng Đại học Khoa học Tụ nhiên, ĐHQGHN, 334 Nguyễn Trãi, Thanh Xuân, Hà Nội, Việt Nam \\ ${ }^{2}$ Hội Địa vật lý Việt Nam, A8/18 Hoàng Quốc Việt, Cầu Giấy, Hà Nội, Việt Nam
}

Nhận ngày 11 tháng 4 năm 2019

Chỉnh sửa ngày 15 tháng 5 năm 2019; Chấp nhận đăng ngày 06 tháng 6 năm 2019

\begin{abstract}
Tóm tắt: Xây dựng quy trình minh giải mặt cắt địa chấn nông phân giải cao theo quan điểm địa chất trầm tích là nhiệm vụ hết sức cấp thiết. Quy trình minh giải có thể chia ra các bước sau đây: (1) Phân chia ranh giới các phức tập (sequence) dựa trên các bề mặt bất chỉnh hợp có dấu hiệu bào mòn của lòng sông; (2) Phân tích tướng và cộng sinh tướng theo không gian và theo thời gian trong mối quan hệ với sự thay đổi mực nước biển toàn cầu; (3) Phân chia ranh giới các miền hệ thống: miền hệ thống trầm tích biển thấp (LST); miền hệ thống trầm tích biển tiến (TST); miền hệ thống trầm tích biến cao (HST). Trên cơ sở đó Trần Nghi (2012) đã thiết lập công thức tồng quát tích hợp giữa tướng trầm tích và các miền hệ thống như sau:
\end{abstract}

(1) $\mathrm{Li}_{\mathrm{LST}}=\operatorname{arLST}+\operatorname{amrLST} ;(2) \mathrm{Li}_{\mathrm{TST}}=\operatorname{atTST}+\operatorname{amtTST}+\operatorname{mtTST} ;$ (3) $\mathrm{Li}_{\mathrm{HST}}=\operatorname{ahTST}+\operatorname{amhTST}$ Trong đó, Li- Tướng trầm tích; ar- Tướng aluvi biển thấp; at- Tướng aluvi biển tiến; ah- Tướng aluvi biển cao; amr- Tướng châu thổ biển thấp; amh- Tướng châu thổ biển cao; amt- Tướng ven biển biển tiến; mt- Tướng biển nông biển tiến cực đại.

Kết quả đã xác định được chính xác vị trí các lòng sông cổ và lịch sử thay đổi của chúng ở khu vực biển nông ven bờ của châu thổ Sông Hồng. Trước năm 1787 lòng Sông Hồng cổ có quy mô lớn nhất chảy về biển qua cửa Hà Lạn (T22-1) còn lòng sông đổ ra cửa Ba Lạt (T12) chỉ là một phụ lưu của Sông Hồng cổ mà thôi. Ranh giới các phức hệ tướng trong mặt cắt địa chấn theo phương thẳng đứng (từ dưới lên) được xác định như sau: $\operatorname{arLSTQ}_{1}{ }^{3 \mathrm{~b}} \rightarrow \mathrm{atSTT}_{2}{ }^{1} \rightarrow \mathrm{amt}_{1} \mathrm{TSTQ}_{2}{ }^{1-2} \rightarrow \mathrm{amt}_{2} \mathrm{TSTQ}_{2}{ }^{1-2} \rightarrow$ $\mathrm{mtTSTQ}_{2}{ }^{2} \rightarrow \mathrm{amhQ}_{2}{ }^{3}$.

Tù khóa: Tướng trầm tích, cộng sinh tướng, trường sóng, miền hệ thống trầm tích, tướng aluvi biển thấp (arLST).

\footnotetext{
* Tác giả liên hệ:

Địa chi email: quynhanthu@gmail.com
}

https://doi.org/10.25073/2588-1094/vnuees.4380 


\section{Mở đầu}

Minh giải mặt cắt địa chấn nông phân giải cao là phương pháp hết sức quan trọng để phân chia các phức hệ và miền hệ thống (LST, TST, HST), phân tích tướng và giải đoán các mỏ sa khoáng chôn vùi. Tuy nhiên, các trường sóng của mặt cắt địa chấn thu được vẫn là thông tin gián tiếp nên việc minh giải để đáp ứng mục tiêu và yêu cầu đặt ra không hề đơn giản thậm chí cho ra những kết quả sai lệch với thực tế. Để kết quả minh giải được chính xác đòi hỏi người minh giải phải có kiến thức toàn diện cả địa vật lý và kiến thức về địa chất trầm tích, đặc biệt là trầm tích Đệ Tứ. Hai khối kiến thức này phải được tích hợp nhuần nhuyễn dựa trên lý thuyết trầm tích luận, kinh nghiệm thực tiễn nghiên cứu trên đất liền và sự vận dụng một cách sáng tạo đối với các đối tượng địa chất trầm tích dưới biển.

Địa tầng trầm tích Đệ Tứ trên đất liền và dưới thềm lục địa là những thực thể địa chất trầm tích được thành tạo liên quan đến sự thay đổi mực nước và chuyển động kiến tạo. Vì vậy tướng trầm tích và thành phần thạch học sắp xếp có quy luật theo không gian và thời gian. Theo thời gian chúng có tính chu kỳ và theo không gian chúng có tính cộng sinh theo nguyên lý chuyển tướng. Trường sóng địa chấn với tướng trầm tích và cấu tạo của các lớp trầm tích có mối quan hệ nhân quả như hình với bóng. Trầm tích có cấu trúc chu kỳ tất yếu các trường sóng địa chấn cũng có chu kỳ. Trầm tích có cấu tạo nêm tăng trưởng của châu thổ ngầm tất yếu trên mặt cắt địa chấn sẽ thấy rõ các trường sóng địa chấn có cấu tạo xích ma tăng trưởng. Trầm tích có cấu tạo phân lớp ngang song song của biển nông tất yếu sẽ có trường sóng phản xạ mạnh thanh nét song song nằm ngang. Đặc biệt khi thành phần thạch học của các lớp đá trầm tích thay đồi đột ngột theo phương thẳng đứng do gián đoạn trầm tích thậm chí có bề mặt bào mòn do lòng sông thì trong mặt địa chấn sẽ thể hiện rất rõ ranh giới phản xạ của 2 tập địa chấn. Nằm trên các ranh giới bào mòn cắt xẻ này, đặc biệt nằm trên các hố đào khoét hình chữ $\mathrm{V}$ của lòng sông thấy rõ trường sóng thô, hỗn độn đó là hình ảnh "sao chụp" lại của một thực thể trầm tích hạt thô (sạn, cát) có cấu tạo phân lớp xiên chéo đồng hướng của lòng sông.

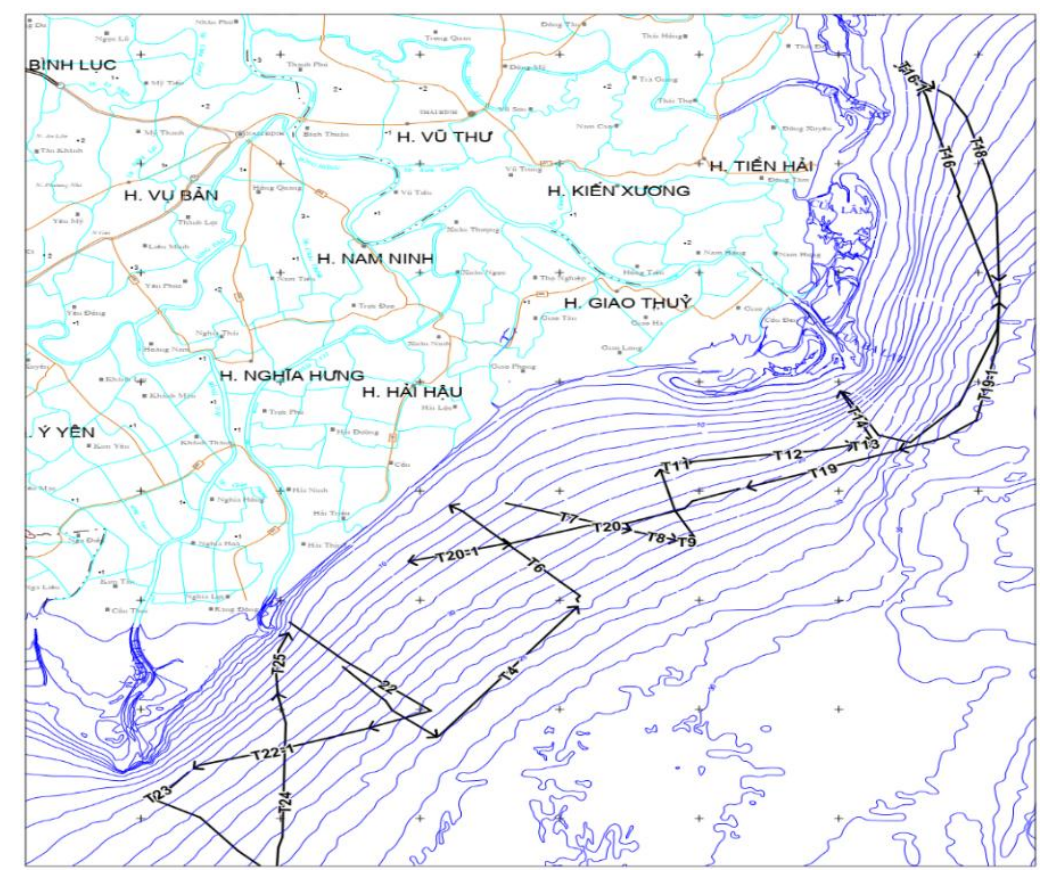

Hình 1. Sơ đồ phân bố các tuyến địa chấn nông phân giải cao vùng biển ven bờ châu thổ Sông Hồng được đo ghi năm 2017 (Đề tài KC-09-02/16-20). 
Nội dung bài báo sẽ giới thiệu phương pháp minh giải mặt cắt địa chấn nông phân giải cao dựa trên sự tích hợp giữa cộng sinh tướng và địa tầng phân tập trong mối quan hệ với sự thay đồi mực nước biển. Từ đó xây dựng quy trình và kỹ năng minh giải nhằm làm sáng tỏ các quy luật sau đây: (1) Quy luật quan hệ nhân quả giữa tướng trầm tích và sự thay đổi mực nước biển toàn cầu và chuyển động kiến tạo; (2) Quy luật quan hệ giữa các trường sóng địa chấn với các kiểu tướng và môi trường trầm tích; (3) Quy luật cộng sinh tướng theo thời gian và theo không gian.

Tính khoa học và ứng dụng của quy trình này được kiểm chứng bằng kết quả minh giải 15 mặt cắt địa chấn nông phân giải cao khu vực biển nông ven bờ của châu thổ Sông Hồng do đề tài KC-09-02/16-20 đã tiến hành đo ghi bằng máy địa chấn hiện đại.

\section{Kết quả nghiên cứu}

\section{1) Co sở khoa họ xây dụng quy trình}

- Khái niệm về chu kỳ và phức tập

- Chu kỳ thay đổi mực nước biển toàn cầu (global sea level change) trong Đệ Tứ

- Chu kỳ trầm tích Đệ Tứ ở Việt Nam (Quarternary sedimentary cycle)

- Phân tích tướng (lithofacies analysis) và địa tầng phân tập (sequence stratigraphy)

\section{(1) Khái niệm về chu kỳ và phúc tập}

\section{Khái niệm về chu kỳ trầm tích}

Trần Nghi $[1,2]$ đã định nghĩa chu kỳ trầm tích Đệ Tứ Đồng bằng Sông Hồng như sau:"'Chu kỳ trầm tích là sự lặp đi lặp lại của các phức hệ tướng trầm tích trong mối quan hệ với sự thay đổi mực nước biển toàn cầu; mở đầu mỗi chu kỳ là phức hệ tướng aluvi nằm trên bề mặt bào mòn cắt xẻ của lòng sông và kết thúc chu kỳ là phức hệ tướng châu thổ".

Định nghĩa này gồm 3 nội dung: (1) Ranh giới các chu kỳ là bề mặt bào mòn cắt xẻ của lòng sông; (2) Sự lặp đi lặp lại của 3 phức hệ tướng trầm tích từ dưới lên trong mỗi chu kỳ, gồm phức hệ tướng aluvi biển thoái, phức hệ tướng ven biển biển tiến; và phức hệ tướng châu thổ biển cao; (3) Chọn chu kỳ thay đổi mực nước biển theo phương án 33' (hình 2). Theo phương án này mối quan hệ giữa chu kỳ trầm tích và sự thay đổi mực nước biển toàn cầu được thể hiện như sau: (1) mực nước biển thấp nhất là ứng với thời điểm kết thúc phức hệ tướng trầm tích aluvi; (2) mực nước biển cao nhất là ứng với kết thúc phức hệ tướng vũng vịnh biển tiến cực đại.

\section{Khái niệm về phức tập}

Trần Nghi et al [3-5] đã nghiên cứu địa tầng phân tập trên cơ sở phân tích tướng và mối quan hệ giữa tiến hóa trầm tích với sự thay đổi mực nước biển toàn cầu và chuyển động kiến tạo và định nghĩa địa tầng phân tập như sau: "Địa tầng phân tập là sự sắp xếp có quy luật của các tuoóng và nhóm tuóng theo không gian và theo thời gian trong mối quan hệ với sụ thay đổi mực nước biển toàn cầu và chuyển động kiến tạo". Ranh giới các phức tập (sequence) là bề mặt gián đoạn trầm tích của miền hệ thống trầm tích biển thấp (LST) và miền hệ thống trầm tích biển cao (HST).

Vậy chu kỳ trầm tích chính là phức tập và cả hai đơn vị cơ bản này đều được cấu thành từ ba phức hệ tướng trầm tích (từ dưới lên) là: (1) phức hệ tướng aluvi biển thấp (arLST); (2) phức hệ tướng ven biển biển tiến (amt, mt TST); (3) phức hệ tướng châu thổ biển cao (amh HST).

Khái niệm về không gian tích tụ trầm tích trong các pha biển thoái và biển tiến

Theo Trần Nghi [2], không gian tích tụ trầm tích theo các pha biển thoái và biển tiến là cơ bản giống nhau và trải rộng từ ranh giới của miền xâm thực và miền tích tụ đến trung tâm của các bể trên thềm lục địa. Trầm tích luôn luôn có mặt trên không gian này song chỉ khác nhau về tướng mà thôi. Theo các hướng biển tiến và biển thoái trầm tích sẽ chuyển tướng liên tục theo không gian và theo thời gian. 
(2) Chu kỳ thay đổi mưc nước biển toàn cầu trong Đệ Túu

Đây là chìa khóa để trả lời câu hỏi tại sao lại có chu kỳ trầm tích? Tại sao giữa chu kỳ trầm tích và địa tầng phân tập lại có quan hệ chặt chẽ với nhau thông qua phân tích tướng?

Trần Nghi (2005) và Richard Little (2005) đã tổng kết tuổi của các chu kỳ băng hà và gian băng trên thế giới như sau:

- Băng hà Gunz (biển thoái): có tuổi 1.9-1.4 triệu năm các ngày nay $(\mathrm{BP})$;

- Gian băng Gunz - Mindel (biển tiến): 1.4 0.8 triệu năm $\mathrm{BP}$;

- Băng hà Mindel (biển thoái): 800 - 402 ngàn năm $\mathrm{BP}$
- Gian băng Mindel - Riss (biển tiến): 402 191 ngàn năm BP;

- Băng hà Riss (biển thoái): 191-130 ngàn năm BP; $\mathrm{BP}$;

- Gian băng (biển tiến): 130 - 83 ngàn năm

- Băng hà Wurm 1 (biển thoái): 83 - 50 ngàn năm BP;

- Gian băng Wurm 1-Wurm 2: 50 - 40 ngàn năm BP;

- Băng hà Wurm 2: 40 - 18 ngàn năm $\mathrm{BP}$;

- Biển tiến Flandrian: 18 - 5 ngàn năm BP.

(3) Chu kỳ trầm tích Đệ Tư của đồng bằng Sông Hồng

Bảng 1. Chu kỳ trầm tích Đệ Tứ của đồng bằng Sông Hồng (Trần Nghi, 2018)

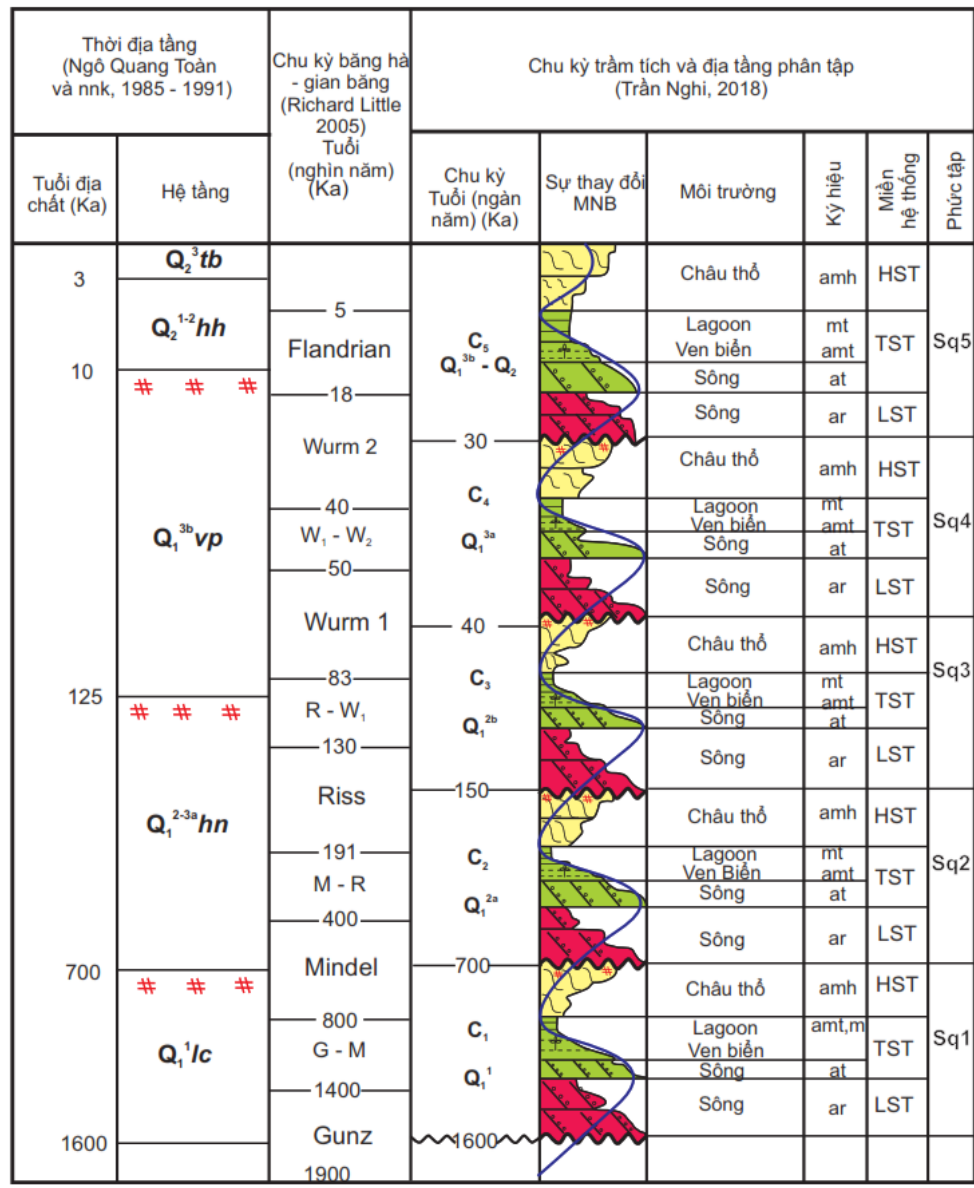


Trần Nghi (2018) [5] đã công bố kết quả phân chia 5 chu kì trầm tích Đệ Tứ ở Việt Nam do ảnh hưởng của 5 chu kỳ băng hà/gian băng (biển thoái/biển tiến) toàn cầu của Richard Little đã tổng kết như sau:

- Chu kì 1: Pleistocen sớm $\left(\mathrm{Q}_{1}{ }^{1}\right)$

- Chu kì 2: Pleistocen giữa phần sớm $\left(\mathrm{Q}_{1}{ }^{2 \mathrm{a}}\right)$

- Chu kì 3: Pleistocen giữa phần muộn $\left(\mathrm{Q}_{1}{ }^{2 \mathrm{~b}}\right)$

- Chu kì 4: Pleistocen muộn phần sớm $\left(\mathrm{Q}_{1}{ }^{3 \mathrm{a}}\right)$

- Chu kì 5: Pleistocen muộn phần muộnHolocen $\left(\mathrm{Q}_{1}{ }^{3 \mathrm{~b}}-\mathrm{Q}_{2}\right)$

Mỗi chu kì trầm tích này tương ứng với một phức tập (sequence), được cấu thành bởi 3 phức hệ tướng (từ dưới lên): (1) Phức hệ tướng cát sạn aluvi biển thấp (arLST); (2) Phức hệ tướng cát bột aluvi, cát bùn sông - biển và sét vũng vịnh thuộc miền hệ thống trầm tích biển tiến [ $(\mathrm{at}+\mathrm{amt}$ $+m t) T S T]$ và (3) Phức hệ tướng bột sét châu thổ biển cao (amhHST) (Bảng 1)

(4) Tướng trầm tích và địa tầng phân tập

Công thức tích hợp giữa cộng sinh tướng và miền hệ thống

Dựa trên mối quan hệ giữa tướng trầm tích và miền hệ thống (Trần Nghi, 2014, 2018) [4] đã thiết lập 3 công thức tổng quát tích hợp giữa cộng sinh tướng và miền hệ thống của trầm tích Đệ Tứ đồng bằng Sông Hồng và biển ven bờ như sau:
Các tướng trong miền hệ thống trầm tích biển thấp (LST): $\mathbf{L i}_{\mathrm{LST}}=(\mathbf{a r}+\mathbf{a m r}) \mathbf{L S T}$

Các tướng trong miền hệ thống trầm tích biển tiến (TST): $\mathbf{L i}_{\mathrm{TST}}=(\mathbf{a t}+\mathbf{a m t}+\mathbf{m t}) \mathbf{T S T}$

Các tướng trong miền hệ thống trầm tích biển cao (HST): $\mathbf{L i}_{\mathrm{HST}}=(\mathbf{a h}+\mathbf{a m h}) \mathbf{H S T}$

Trong đó: ar: Phức hệ tướng aluvi biển thấp at: Phức hệ tướng aluvi biển tiến

ah: Phức hệ tướng aluvi biển cao amr: Phức hệ tướng châu thổ biển thấp amt: Phức hệ tướng ven biển biển tiến biển tiến

mt: Phức hệ tướng biển nông - vũng vịnh

Đã từ lâu các nhà địa chất Đệ Tứ Việt Nam đã dùng kí hiệu chữ viết tắt để gọi nguồn gốc của trầm tích. Ví dụ a để chỉ nguồn gốc aluvi; am để chỉ nguồn gốc sông-biển; $\mathrm{amb}$ để chỉ nguồn gốc sông - biển đầm lầy. Cách gọi "nguồn gốc" như vậy là không chuẩn xác vì thực chất đó chính là tướng và môi trường trầm tích. Còn "nguồn gốc" đúng nghĩa của nó là nguồn gốc của vật liệu trầm tích. Ví dụ thạch anh vụn có nguồn gốc từ khối đá granit, ilmenit có nguồn gốc từ khối đá gabro... Vì vậy các kí hiệu nói trên được dùng trong bài báo này nói riêng và các văn liệu trầm tích nói chung đều có nghĩa là tướng và môi trường trầm tích.

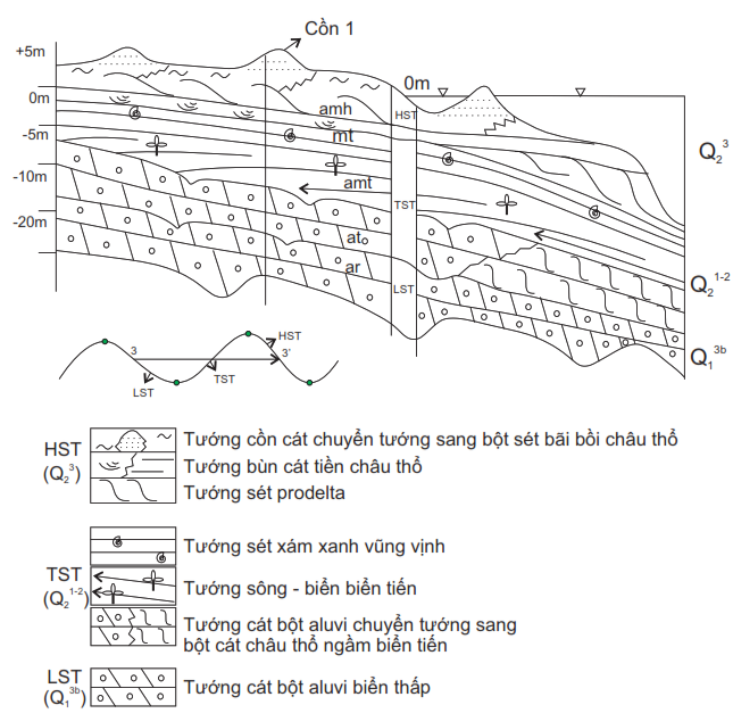

Hình 2. Sơ đồ chuyển tướng theo không gian và thời gian đới bờ châu thổ Sông Hồng. 
2. Quy trình minh giải măt cắt địa chấn nông phân giải cao vùng biển ven bò̀ châu thổ Sông Hồng

Bảng 2. Các tuyến đo địa chấn nông phân giải cao khu vực Ba Lạt - Cửa Đáy được sử dụng trong bài báo

\begin{tabular}{llll}
\hline STT & Tên tuyến & STT & Tên tuyến \\
\hline 1 & T04 & 5 & T14-CH1 \\
2 & T06 CH1 & 6 & T16 CH1 \\
3 & T12 CH1 & 7 & T18 CH1 \\
4 & T22 & 8 & T23-CH1 \\
\hline
\end{tabular}

(1) Bước 1: Xác định ranh giới giũa các phức tập (sequences) dụa trên 2 dấu hiệu

Xác định ranh giới giũua các phức tập (sequences) dựa trên ranh giới chu kỳ trầm tích (sedimentarycycles): (ar+amr)LST/(ah+amh)HST

Trong một mặt cắt địa chấn nông phân giải cao việc xác định ranh giới giữa các phức tập hết sức quan trọng. Nếu xác định ranh giới phức tập sai tất yếu sẽ dẫn đến những sai lầm khác như ranh giới các miền hệ thống và các phức hệ tướng trong mối quan hệ với sự thay đổi mực nước biển. Ranh giới phức tập được xác định đơn giản nhất là lấy trùng với ranh giới chu kỳ trầm tích do Trần Nghi đề nghị $(2012,2018)$ [4]. Đặc trưng các chu kỳ trầm tích Đệ Tứ trên đồng bằng Sông Hồng là sự lặp đi lặp lại các phức hệ tướng trầm tích và thành phần độ hạt. Bắt đầu mỗi chu kỳ là thành phần hạt thô của phức hệ tướng aluvi nằm trên bề mặt bào mòn cắt xẻ của lòng sông và kết thúc mỗi chu kỳ là thành phần hạt mịn của phức hệ tướng châu thổ. Riêng đối với trầm tích trên thềm lục địa ranh giới giữa các chu kỳ thường là ranh giới bất chỉnh hợp địa tầng. Ranh giới chu kỳ không có dấu hiệu bào mòn nhưng thành phần độ hạt khác nhau do mực nước biển thay đổi. Chúng có quan hệ chỉnh hợp với nhau và có cấu tạo nằm ngang song song đặc trưng của môi trường biển nông.

a) Ranh giới chu kỳ trầm tích trùng với bề mặt bào mòn cắt xẻ của lòng sông khi biển thoái toàn cầu đạt cực tiểu (hình $3,4,5,8$ ) b) Ranh giới của 2 phức hệ tướng thuộc 2 miền hệ thống trầm tích biển thấp và biển cao của châu thổ Sông Hồng được rút gọn như sau:

$$
\mathrm{LST} / \mathrm{HST}=(\mathrm{ar}+\mathrm{amr}) /(\mathrm{ah}+\mathrm{amh})
$$

\section{(2) Bước 2: Xác định ranh giới giữa các phức hệ tuớng trầm tích}

a) Xác định ranh giới giữa phức hệ tướng aluvi biển tiến và phức hệ aluvi biển thấp: atTST/arLST.

Trên mặt cắt địa chấn nông phân giải cao thấy rõ 2 nhịp tướng aluvi phủ bất chỉnh hợp lên nhau (hình 3-8). Nhịp aluvi dưới thuộc miền hệ thống biển thấp (arLST) còn nhịp aluvi trên thuộc miền hệ thống trầm tích biển tiến (atTST). Điều đó được giải thích như sau: khi biển đang tiến (TST) nhưng đường bờ vẫn còn nằm ngoài thềm lục địa nên tại khu vực đới bờ vẫn là môi trường aluvi (at). Mỗi nhịp có 2 kiểu trường sóng khác nhau từ dưới lên: (1) Lớp dưới các trường sóng thô, hỗn độn đứt đoạn, nghiêng định hướng, tần số phản xạ thấp. Điều đó phản ánh trầm tích hạt thô (cát, sạn) có cấu tạo phân lớp xiên chéo đồng hướng lòng sông; (2) Lớp trên trường sóng mịn đứt đoạn, tần số phản xạ mạnh hơn, biểu hiện trầm tích bột sét bãi bồi cấu tạo phân lớp sóng xiên đứt đoạn.

b) Xác định ranh giới giữa phức hệ tướng ven biển biển tiến và phức hệ tướng aluvi biển tiến (amtTST/atTST)

Khi biển đã tiến vào khu vực đới bờ sẽ tạo nên bề mặt bào mòn biển tiến trên nhịp tướng aluvi biển tiến. Môi trường ven biển được đặc trưng bởi trường sóng có cấu tạo kề áp (onlap) (hình $3,4,5,8$ ).

c) Xác định ranh giới giữa 3 phức hệ tướng (từ dưới lên): (1) Phức hệ tướng aluvi biển thấp (arLST)

Trường sóng thô, đứt đoạn phản xạ yếu; (2) Phức hệ tướng aluvi biển tiến (atTST). Trường sóng tương tự phức hệ tướng aluvi biển thấp; (3) Phức hệ tướng châu thổ ngầm biển tiến ( $\left.\mathrm{amt}_{1} \mathrm{TST}\right)$. Trường sóng có cấu tạo phủ chồng lùi (downlap) hay gọi là nêm tăng trưởng phản ánh môi trường dư thừa trầm tích và (4) Phức hệ 
tướng ven biển biển tiến $\left(\mathrm{amt}_{2} \mathrm{TST}\right)$. Trường sóng có cấu tạo kề áp (onlap). Tướng trầm tích chủ yếu là cát bùn bãi triều biển tiến, đầm lầy ven biển biển tiến, bùn estuary.

d) Xác định ranh giới giữa 2 phức hệ tướng ven biển và biển tiến cực đại

(1) Phức hệ tướng ven biển $\left(\mathrm{amt}_{2} \mathrm{TST}\right)$. Trường sóng có cấu tạo kề áp (onlap) gồm các tướng trầm tích: cát bùn bãi triều biển tiến, đầm lầy ven biển biển tiến và bùn estuary; (2) Phức hệ tướng sét xám xanh vũng vịnh (mtTST). Trường sóng nằm ngang song song mịn, phản xạ mạnh đặc trưng cho tướng sét vũng vịnh (hình $5,9,10)$.

đ) Xác định ranh giới giữa 2 phức hệ tướng biển tiến cực đại và tướng châu thổ ngầm
(1) Phức hệ tướng sét xám xanh vũng vịnh (mtTST);

(2) Phức hệ tướng bột sét châu thổ ngầm hiện đại (amhHST). Trường sóng có cấu tạo downlap (nêm tăng trưởng) (hình 5).

(3) Bước 3: Xác định ranh giới giữa các miền hệ thống

a) Ranh giới giữa miền hệ thống trầm tích biển tiến và miền hệ thống trầm tích biển thấp: (at+ mt +amt) TST/ (ar +amr) LST;

b) Ranh giới giữa miền hệ thống trầm tích biển cao với miền hệ thống trầm tích biển tiến: $(\mathrm{ah}+\mathrm{amh}) \mathrm{HST} /(\mathrm{at}+\mathrm{mt}+\mathrm{amt}) \mathrm{TST}$
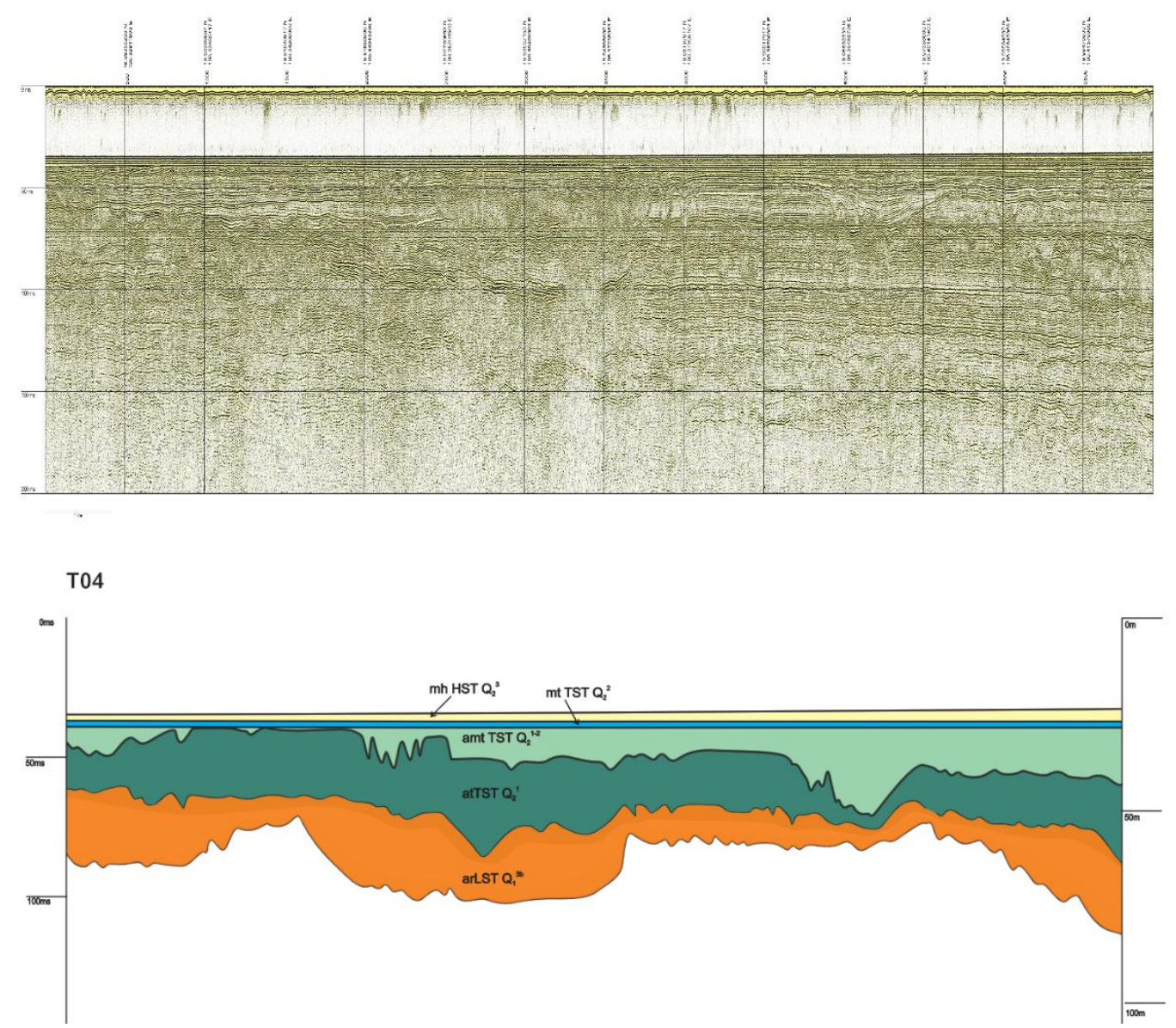

Hình 3. Mặt cắt địa chấn tuyến T04 Cửa Hà Lạn - Sông Sò. 

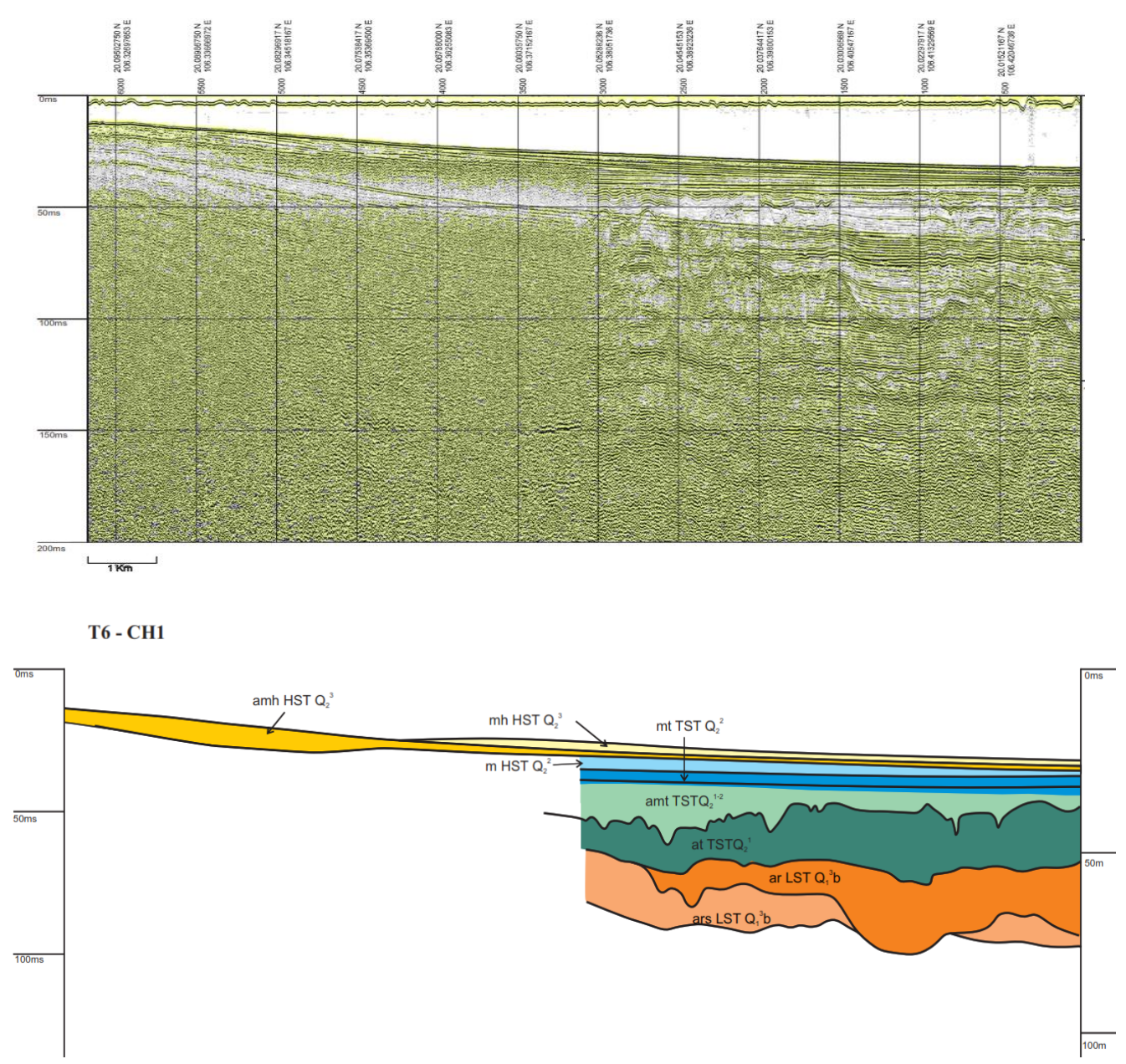

Hình 4. Mặt cắt địa chấn tuyến T06 Cửa Hà Lạn - Sông Sò.

3) Đặc điểm cộng sinh tướng trong mối quan hệ với sụ thay đồi mực nước biển

a) Phức hệ tướng aluvi biển thấp ( $\operatorname{arLST}$ )

Mặt cắt tuyến T14-CH1 (hình 7) và mặt cắt tuyến T6 -CH1 (hình 4) thấy rõ dấu hiệu đào khoét cắt xẻ của lòng Sông Hồng cổ hình chữ $\mathrm{V}$ nằm theo hướng đông nam của cửa Hà Lạn (Hải Hậu). Kích thước lòng sông rộng khoảng 5 km, sâu khoảng $15 \mathrm{~m}$. Trường sóng địa chấn tại vị trí của lòng sông thô nét, hổn độn biểu hiện cấu tạo phân lớp xiên chéo của tướng cát lòng sông đồng bằng thuộc miền hệ thống biển thấp (arLST). Dấu vết lòng sông có quy mô lớn này là minh chứng cho lòng Sông Hồng cổ chảy từ Sông Sò ra cửa Hà Lạn hướng về phía đông nam qua vị trí của 2 mặt cắt nói trên $[3,6]$. Trong lúc đó, mặt cắt T12-CH1 trước cửa sông Ba Lạt đã cho thấy trong miền hệ thống biển thấp (arLST) ở khu vực cửa sông $\mathrm{Ba}$ Lạt không có dấu vết đào khoét của lòng sông có quy mô lớn (hình 5).

Những vị trí lòng sông khác có quy mô nhỏ hơn được phát hiện trên các mặt cắt T12 - CH1 (cửa $\mathrm{Ba}$ Lat, hình 5), T16 - CH1, T18 - CH1 (cửa Lân, cửa Trà Lý và cửa Thái Bình) (hình 8,9 ), T22 (cửa sông Ninh Cơ, hình 6), T23 - $\mathrm{CH} 1$ (cửa sông Đáy, hình 10). Đây là lòng sông của các phụ lưu Sông Hồng trong quá trình bồi tụ tăng trưởng đồng bằng aluvi về phía biển đến độ sâu $100 \mathrm{~m}$ nước - đường bờ biển thấp của băng hà Wurm 2 (50-18 ngàn năm $\mathrm{BP}$ ) [7-9]. 

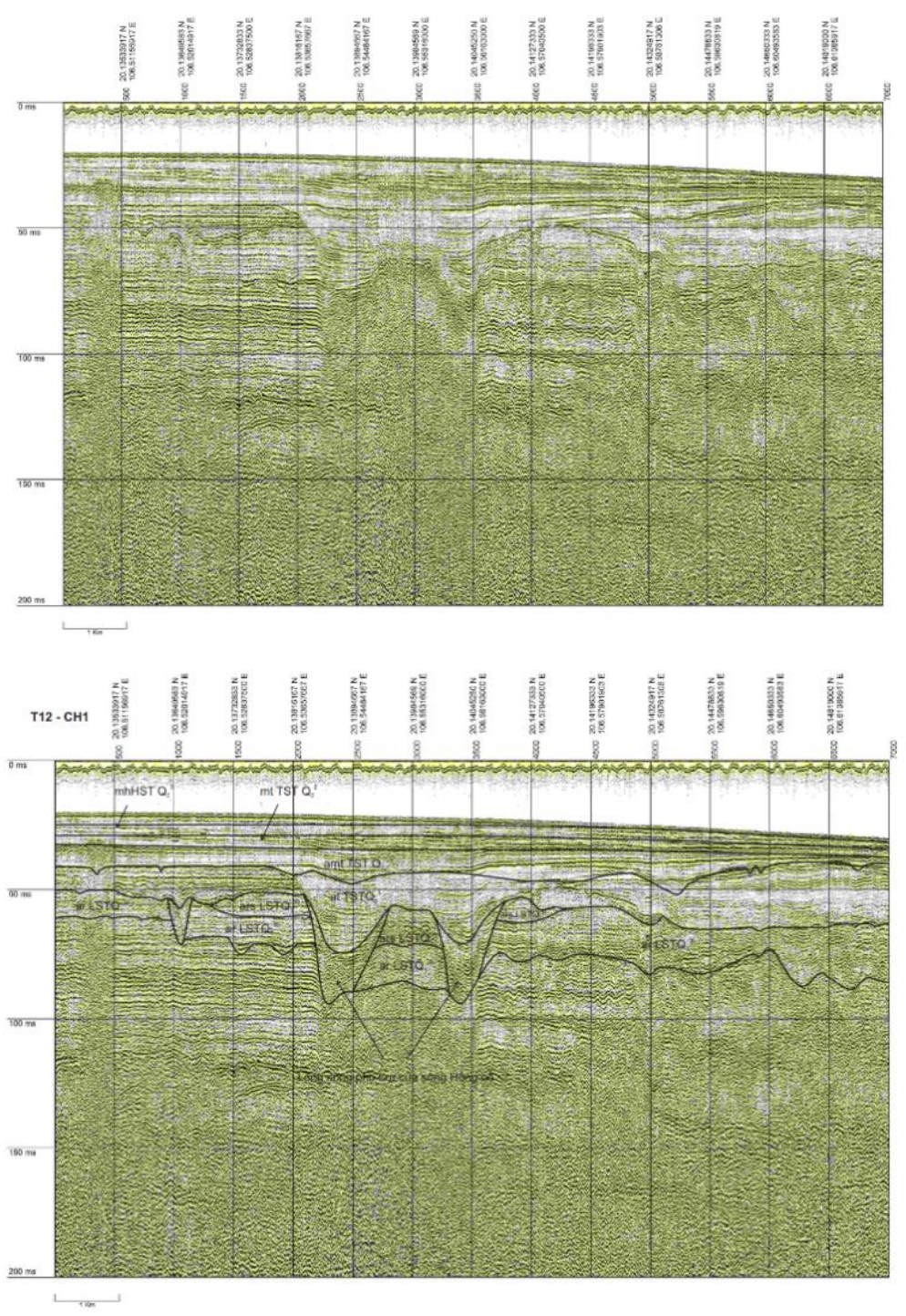

$\mathrm{T} 12 \cdot \mathrm{CH} 1$

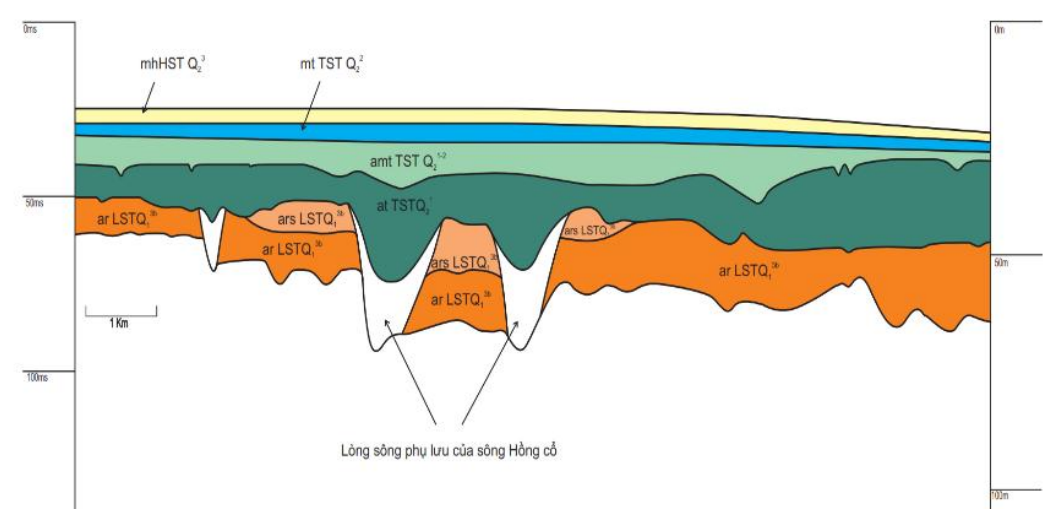

Hình 5. Mặt cắt địa chấn tuyến T12 Cửa Ba Lạt. 

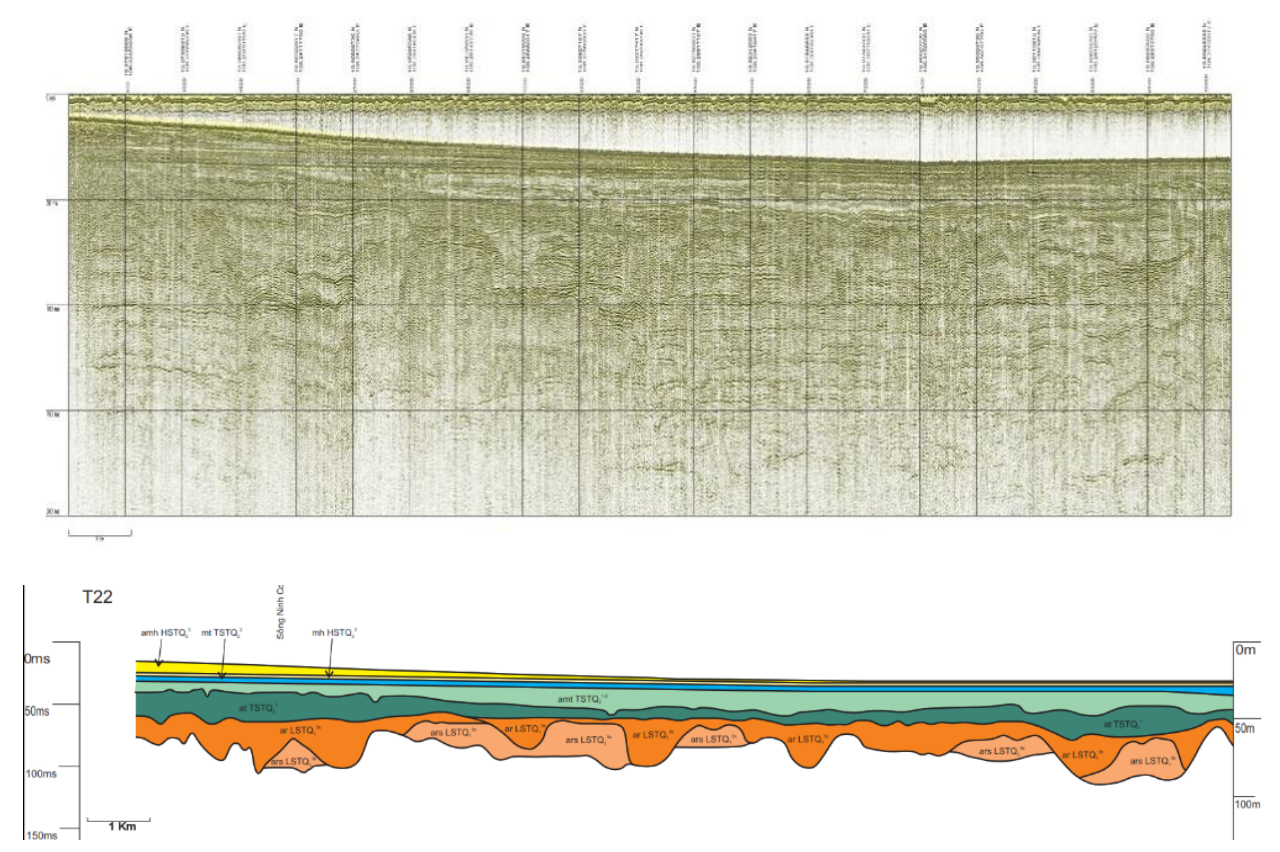

Hình 6. Mặt cắt địa chấn tuyến T22 Cửa Sông Ninh Cơ.
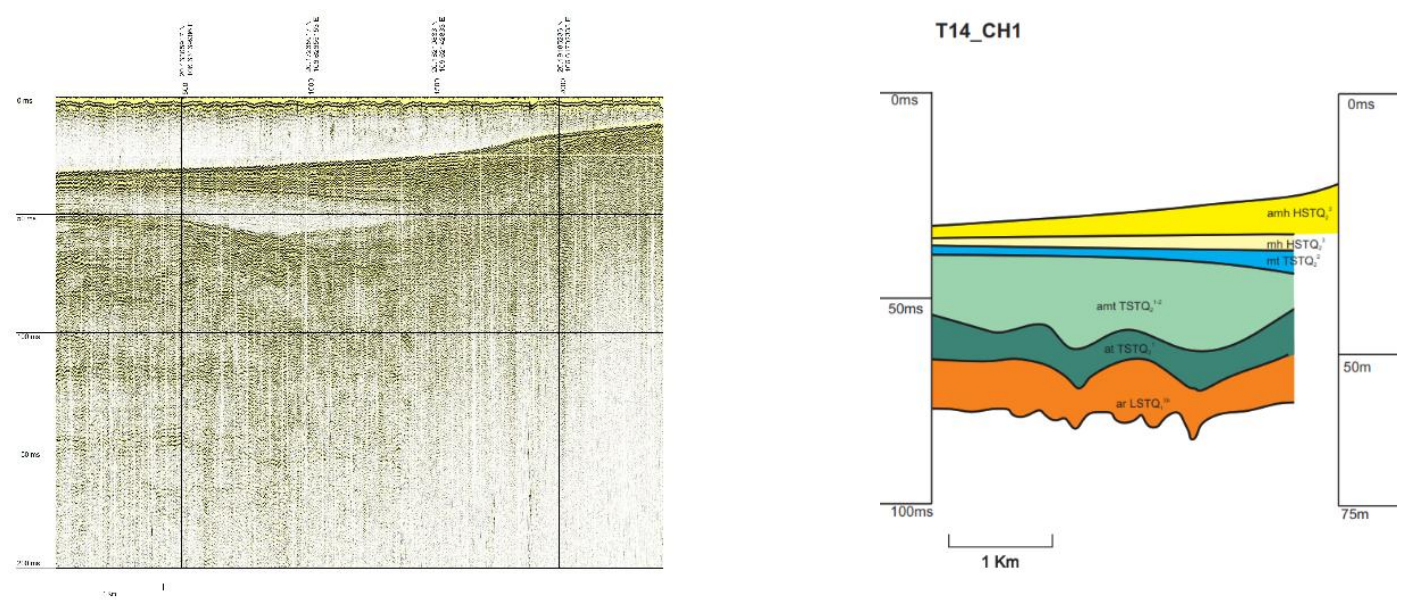

Hình 7. Mặt cắt địa chấn tuyến T14 - CH1 vuông góc Cửa Ba Lạt.

b) Phức hệ tướng ven biển biển tiến Holocen sớm (at, amtTSTQ ${ }_{2}{ }^{1-2}$ )

Phức hệ tướng ven biển là sản phẩm đặc trưng của pha biển tiến Flandrian (18-5ka năm $\mathrm{BP})$. Phức hệ tướng này lan rộng từ $18 \mathrm{ka}-5 \mathrm{ka}$ năm $\mathrm{BP}$ từ độ sâu $100 \mathrm{~m}$ nước của thềm lục địa rồi bao phủ cả đồng bằng Sông Hồng và kết thúc tại đường bờ $+5 \mathrm{~m}$ được đánh dấu bởi các mỏ than bùn trước biển tiến cực đại và ngấn biển trên vách đá vôi ở Ninh Bình có tuổi 6-5ka năm $B P$.

Trên các mặt căt địa chấn vùng biển châu thổ Sông Hồng có thể phân biệt 5 nhóm trường sóng đặc trưng (từ dưới lên) như sau: (1) Tướng aluvi biển tiến (atTST) được đặc trưng bởi trường sóng thô, hỗn độn, thường phản xạ trắng do thành phần trầm tích chủ yếu là cát lòng sông; (2) 
Tướng châu thổ ngầm biển tiến. Trường sóng có cấu tạo nêm tăng trưởng phủ chỉnh hợp trên phức hệ tướng aluvi biển tiển (3) Tướng cát bùn bãi triều biển tiến $\left(\mathrm{amt}_{1} \mathrm{TST}\right)$ phủ trên bề mặt bào mòn do sóng và thủy triều; (4) Tướng bùn sét đầm lầy ven biển biển tiến (amt phân bố cộng sinh với tướng cát bùn bãi triều). Trường sóng địa chấn mịn cấu tạo phủ chồng tiến (onlap); (5) Tướng bùn cát cửa sông estuary. Trên mặt cắt địa chấn thấy rõ các dấu vết đào khoét nông và hẹp tạo thành một hệ thống có quy mô khác nhau nằm trên bề mặt bào mòn biển tiến (TS). Các rãnh đào khoét này sâu nhất là cửa Hà Lạn (Sông Hồng cổ, mặt cắt T04 (hình 3 ) và các rãnh đào khoét có quy mô nhỏ hơn là cửa các phụ lưu như cửa Đáy (hình 10), cửa Ninh Cơ (hình 6), cửa $\mathrm{Ba}$ Lạt (hình 5), cửa Trà Lý và cửa Thái Bình (hình $8,9)$.
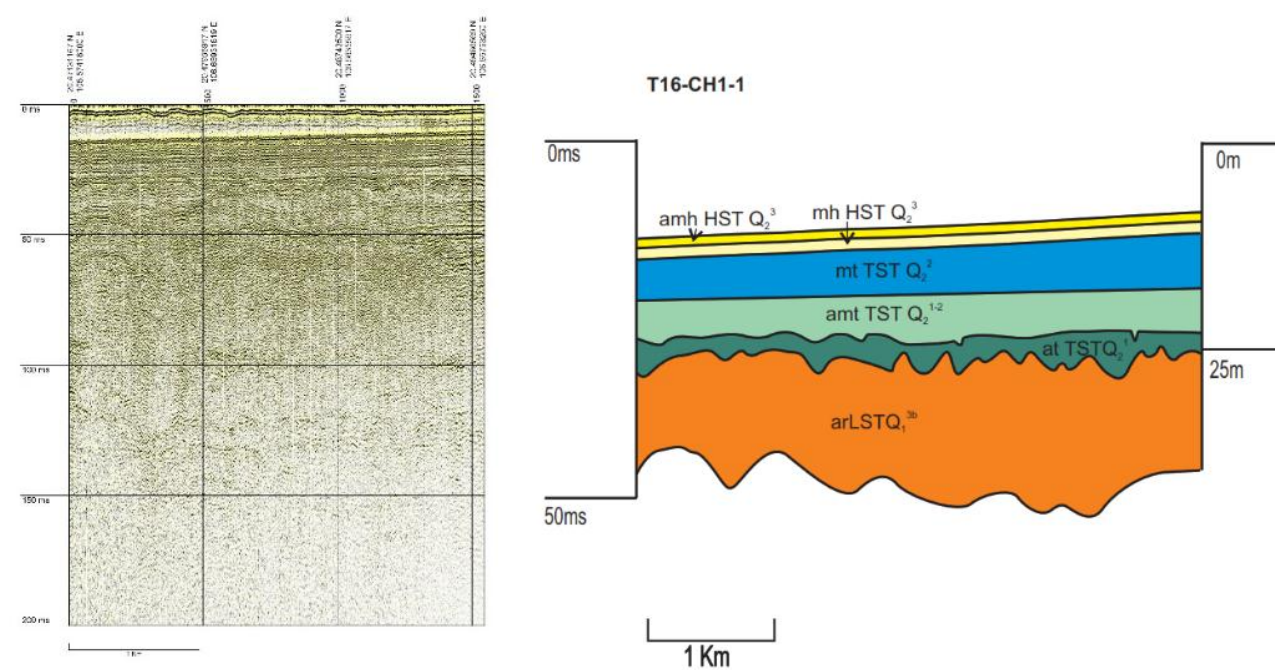

Hình 8. Mặt cắt địa chấn tuyến T16 - CH1 Cửa Trà Lý.

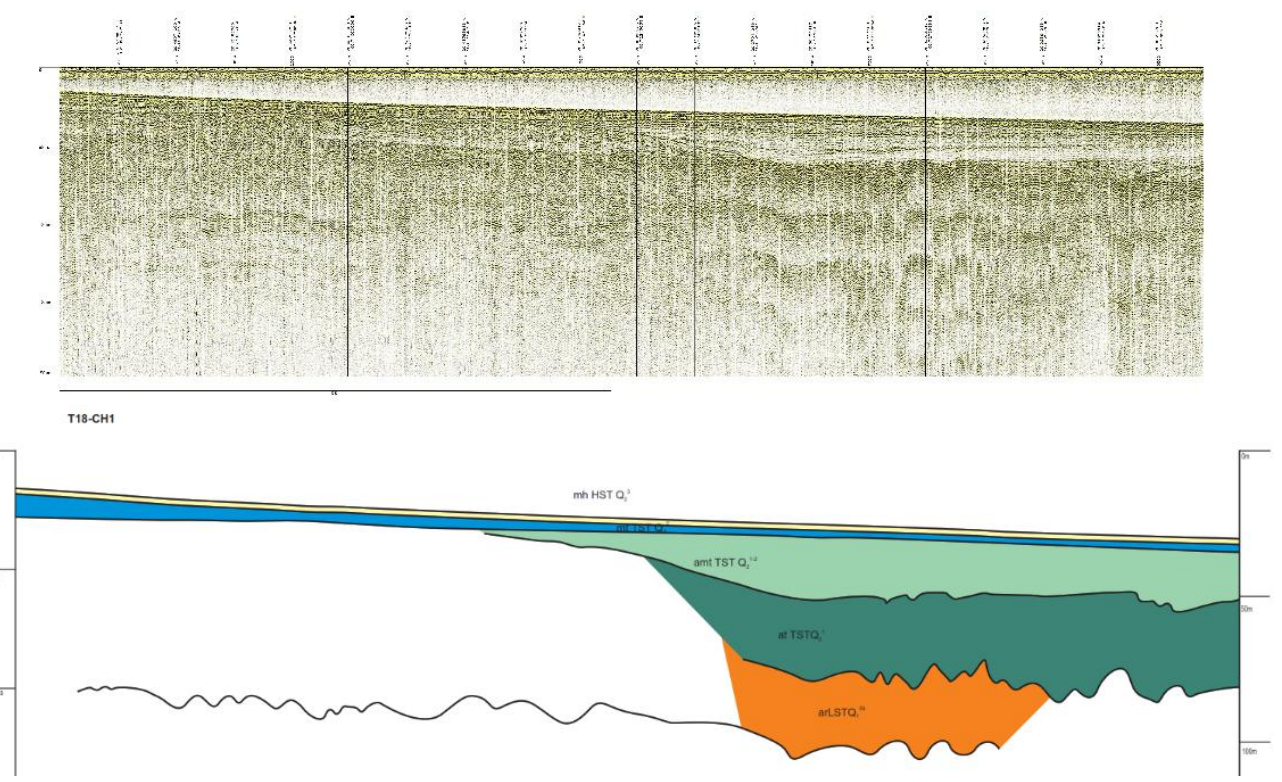

Hình 9. Mặt cắt địa chấn tuyến T18 - CH1 Cửa Thái Bình. 

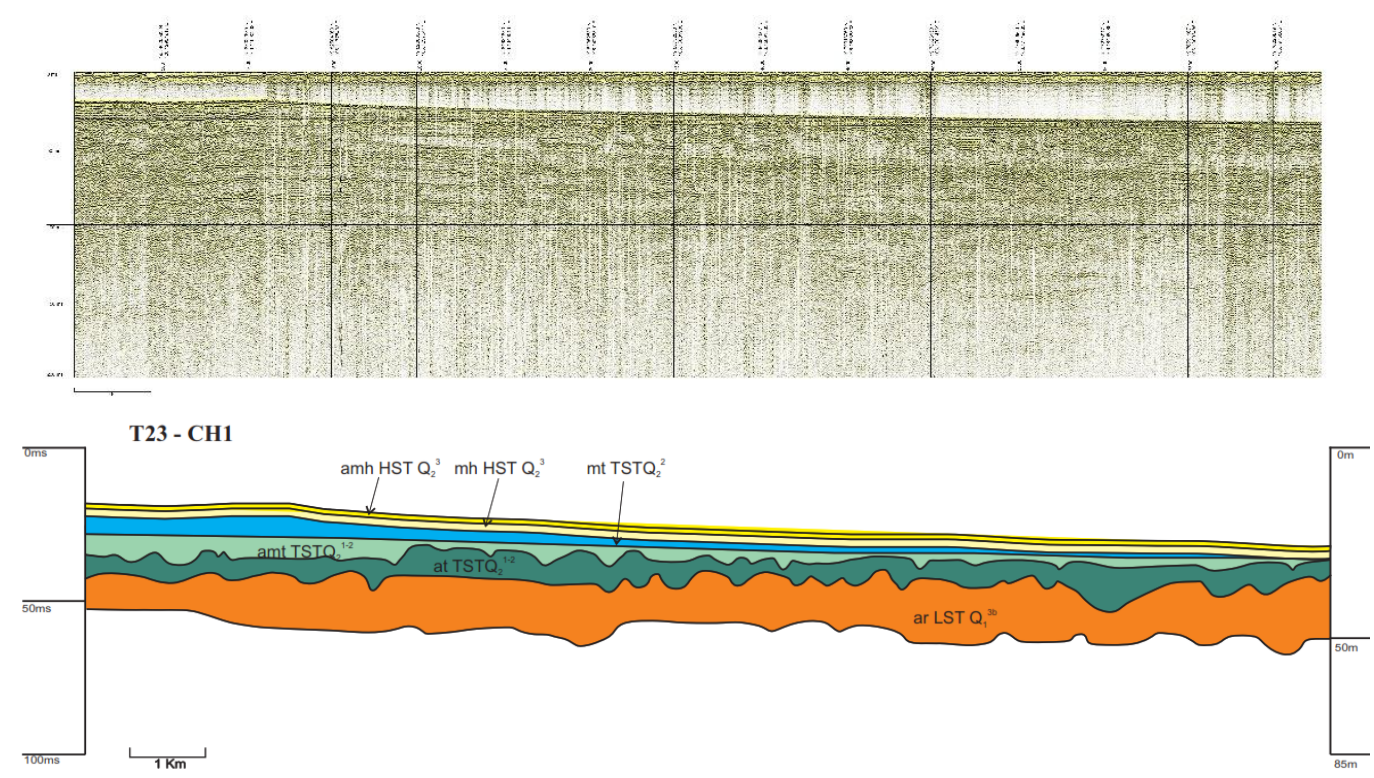

Hình 10. Mặt cắt địa chấn tuyến T23-CH1.

\begin{tabular}{|c|c|c|c|}
\hline \multicolumn{4}{|c|}{ Chú giải: } \\
\hline \multicolumn{2}{|c|}{ - Lòng sông Hồng cổ cắt xẻ quy mô lớn (arLST) } & \multicolumn{2}{|c|}{ - Mặt bào mòn biển tiến lạch triều cắt xẻ (amtTST) } \\
\hline \multicolumn{2}{|c|}{ - Mặt bào mòn aluvi biễn tiến quy mô nhỏ (atTST) } & \multicolumn{2}{|c|}{ - Đồng bằng ngập lụt có trường sóng ngang song song } \\
\hline $\operatorname{arLSTQ}{ }_{1}^{3 b}$ & $\begin{array}{l}\text { Phức hệ tướng aluvi biển thấp } \\
\text { Pleistocen muộn phần muộn }\end{array}$ & amtTSTQ ${ }_{2}^{1-2}$ & $\begin{array}{l}\text { Phức hê̂ tướng ven biễn biễn tiến } \\
\text { Holocen sớm - giữa }\end{array}$ \\
\hline $\operatorname{arsLSTQ}{ }_{1}^{36}$ & $\begin{array}{l}\text { Tướng cồn cát giữa sông } \\
\text { Pleistocen muộn phần muộn }\end{array}$ & $\mathrm{mtTSTQ}_{2}{ }^{2}$ & $\begin{array}{l}\text { Tướng biển nông lagoon biễn tiến } \\
\text { cực đại tiến Holocen muộn phẩn giữa }\end{array}$ \\
\hline atTSTQ ${ }_{2}{ }^{\prime}$ & $\begin{array}{l}\text { Phức hệ tướng aluvi biển tiến } \\
\text { Holocen sớm phần sớm }\end{array}$ & amhHSTQ ${ }_{2}^{3}$ & $\begin{array}{l}\text { Phức hê tướng châu thổ ngầm Holocen } \\
\text { muộn phần muộn }\end{array}$ \\
\hline & & $\mathrm{mhHSTQ}_{2}{ }^{3}$ & $\begin{array}{l}\text { Tướng biển nông ven bờ Holocen muộn } \\
\text { phẩn muộn }\end{array}$ \\
\hline
\end{tabular}

Hình 11. Chú giải các ký hiệu trên mặt cắt địa chấn được minh giải. (mtTST)

c) Phức hệ tướng biển nông biển tiến cực đại

Trường sóng địa chấn của phức hệ tướng vũng vịnh biển tiến cực đại Holocen giữa $\left(\mathrm{mtTSTQ}_{2}{ }^{2}\right)$ có cấu tạo nằm ngang song song đặc trưng cho tướng sét biển nông. Trên đồng bằng Sông Hồng tương ứng với phức hệ tướng trầm tích này là phức hệ tướng sét xám xanh vũng vịnh phân bố rộng khắp có tuổi $6-5 \mathrm{ka} \mathrm{BP}$ được sử dụng như một tầng đánh dấu của hệ tầng Hải Hưng [10-12]. d) Phức hệ tướng trầm tích biển cao (amhHST).

Trên mặt cắt địa chấn nông phân giải cao vuông góc với đường bờ hiện đại (các tuyến T22, T16-CH1) từ bờ ra khơi có thể nhận thấy rõ 3 đới tướng trầm tích: (1) Đới tướng tiền châu thổ. Trường sóng cấu tạo nằm ngang; (2) Đới tướng sườn châu thổ (prodelta). Trường sóng có cấu tạo nêm tăng trưởng; (3) Đới tướng biển nông ven bờ. Trường sóng mịn, phản xạ mạnh cấu tạo nằm ngang song song. (4) Biến động của hệ thống lòng sông trong Pleistocen muộn - Holocen. 
Trong giai đoạn Pleistocen muộn do ảnh hưởng của băng hà Wurm 2 (50-18 ngàn năm BP) Sông Hồng và các phụ lưu đã vươn theo đường bờ biển thoái ra tận độ sâu $10 \mathrm{~m}$ nước [1316]. Giai đoạn này lòng Sông Hồng chảy theo vị trí của sông Sò hiện tại đi qua cửa Hà Lạn và ra thềm lục địa (hình 3). Trên mặt cắt địa chấn T04 thấy rõ quy mô đào khoét cắt xẻ của Sông Hồng rộng và sâu nhất so với các lòng sông Đáy, sông Ninh Cơ, sông Ba Lạt, sông Lân và sông Trà lý (hình 8,9 ). Theo tài liệu lịch sử dư địa chí của huyện Xuân Thủy, tỉnh Nam Định và Trần Nghi (2018) [3] từ 5 ngàn năm $B P$ đến năm 1787 Sông
Hồng vẫn chảy theo Sông Sò đổ ra cửa Hà Lạn. Năm 1787 một cơn lũ lớn đê Sông Hồng bị vỡ làm thu hẹp Sông Hồng tại ngã $3 \mathrm{Ngô}$ Đồng. Từ đó chuyển hướng dòng chảy Sông Hồng đổ về cửa Hà Lạn (Nam Định) sang cửa Ba Lạt vốn là một phụ lưu nhỏ bé của Sông Hồng.

Trên mặt cắt địa chấn tuyến T04 chạy song song với bờ biển Hà Lạn thấy rõ hình ảnh mặt cắt ngang của lòng Sông Hồng cổ trong giai đoạn biển thoái Pleistocen muộn có quy mô lớn hơn nhiều so với lòng sông phụ lưu đổ về cửa Ba Lạt trên tuyến $\mathrm{T} 12$ - $\mathrm{CH} 1$ cùng giai đoạn này (hình 5 ).

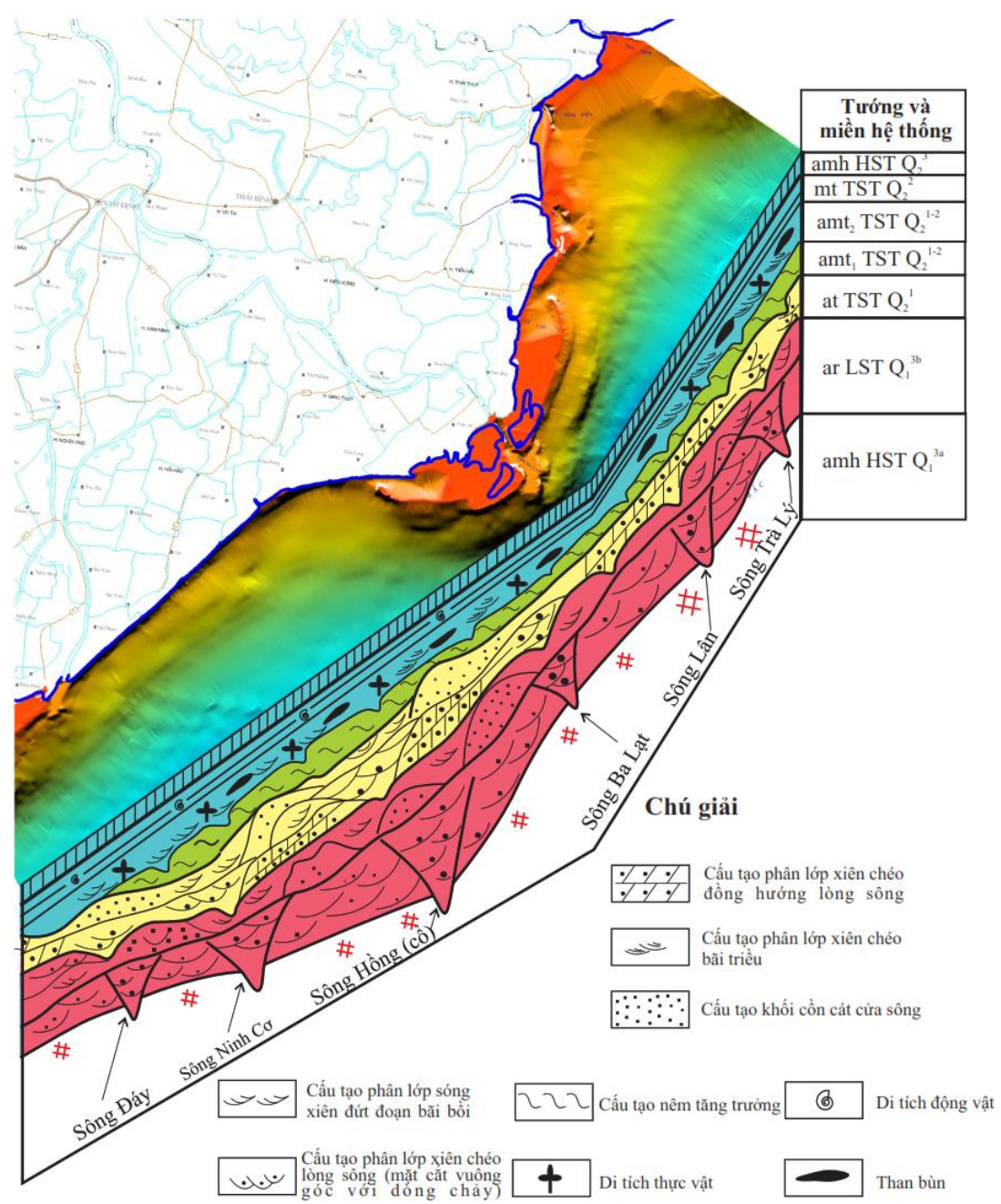

Hình 12. Sơ đồ khối mặt cắt địa chất trầm tích vùng biển ven biển châu thổ Sông Hồng. 


\begin{tabular}{|c|c|c|c|c|}
\hline $\begin{array}{l}3 \text { miền } \\
\text { hệ thống }\end{array}$ & $\begin{array}{l}3 \text { phức } \\
\text { hệ tướng }\end{array}$ & $\begin{array}{l}\text { Ký hiệu } \\
\text { tướng }\end{array}$ & $\begin{array}{l}\text { Mực } \\
\text { nước } \\
\text { biển }\end{array}$ & Tướng trầm tích \\
\hline \multirow{3}{*}{ HST } & & amhdf & & $\begin{array}{l}\begin{array}{l}\text { Tướng bột sét bãi } \\
\text { bồi ĐBCT biến cao }\end{array} \\
\begin{array}{l}\text { Tướng cồn cát } \\
\text { ĐBCT biển cao }\end{array}\end{array}$ \\
\hline & \multirow{2}{*}{$\begin{array}{l}-6- \\
\overline{\overline{1}}-\overline{-} \\
\overline{10}\end{array}$} & amhfr & & $\begin{array}{l}\text { Tướng bùn cát tiền châu thổ } \\
\text { biển cao }\end{array}$ \\
\hline & & amhpr & & Tướng sét prodelta biển cao \\
\hline \multirow{4}{*}{ TST } & \multirow{2}{*}{ Mt } & $\mathrm{mt}$ & & $\begin{array}{l}\text { Tướng sét vũng vịnh biển } \\
\text { tiến }\end{array}$ \\
\hline & & amt & & $\begin{array}{l}\text {-Tướng bùn đầm lầy biển tiến } \\
\text {-Tướng cát bãi triều biển tiến }\end{array}$ \\
\hline & \multirow{2}{*}{ 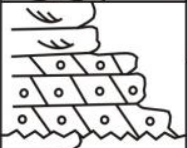 } & atf & & $\begin{array}{l}\text { Tướng bột sét bãi bồi biễn } \\
\text { tiến }\end{array}$ \\
\hline & & atc & & $\begin{array}{l}\text { Tướng cát lòng sông biển } \\
\text { tiến }\end{array}$ \\
\hline \multirow{2}{*}{ LST } & \multirow[b]{2}{*}{$\overline{10}$} & arf & & $\begin{array}{l}\text { Tướng bột sét bãi bồi biển } \\
\text { thấp }\end{array}$ \\
\hline & & arc & & $\begin{array}{l}\text { Tướng cát sạn lòng sông } \\
\text { biển thấp }\end{array}$ \\
\hline
\end{tabular}

Hình 13. Ranh giới giữa các miền hệ thống (LST/TST/HST) và các phức hệ tướng trầm tích ( $\mathrm{ar} / \mathrm{at} / \mathrm{amt} / \mathrm{mt} / \mathrm{amh})$ Pleistocen muộn - Holocen đới bờ châu thổ Sông Hồng.

\section{Kết luận}

1. Minh giải mặt cắt địa chấn nông phân giải cao ở vùng biển nông ven bờ châu thổ Sông Hồng hết sức quan trọng vừa có ý nghĩa về phương pháp vừa có ý nghĩa thực tiễn.

2. Xây dựng quy trình minh giải gồm 3 bước cơ bản:

- Phân chia ranh giới các phức tập (sequence) dựa trên các bề mặt bất chỉnh hợp có dẩu hiệu bào mòn của lòng sông;

- Phân tích tướng và cộng sinh tướng theo không gian và theo thời gian trong mối quan hệ với sự thay đổi mực nước biển

- Phân chia ranh giới các miền hệ thống: miền hệ thống trầm tích biển thấp (LST); miền hệ thống trầm tích biển tiến (TST); miền hệ thống trầm tích biến cao (HST);

3. Thiết lập được công thức tổng quát tích hợp giữa tướng trầm tích và các miền hệ thống:

$$
\mathrm{Li}_{\mathrm{LST}}=\operatorname{arLST}+\operatorname{amrLST}
$$

$$
\begin{aligned}
& \mathrm{Li}_{\mathrm{TST}}=\operatorname{atTST}+\operatorname{amtTST}+\operatorname{mtTST} \\
& \mathrm{Li}_{\mathrm{HST}}=\operatorname{ahTST}+\operatorname{amhTST}
\end{aligned}
$$

4. Xác định được chính xác vị trí lòng sông cổ và sự biến động của hệ thống lòng sông ở khu vực biển nông ven bờ của châu thổ Sông Hồng. Trong đó lòng Sông Hồng cổ có quy mô lớn nhất chảy về biển qua cửa Hà Lạn; lòng sông $B a$ Lạt chỉ là phụ lưu của Sông Hồng cổ.

5. Mỗi một mặt cắt địa chấn nông phân giải cao xác định được ranh giới chính xác các phức hệ tướng theo mặt cắt địa chấn nông phân giải cao (từ dưới lên): $\operatorname{arLSTQ}_{1}{ }^{3 \mathrm{~b}} \rightarrow$ atTST $\mathrm{Q}_{2}{ }^{1} \rightarrow$ $\mathrm{amt}_{1} \mathrm{TSTQ}_{2}{ }^{1-2} \rightarrow \mathrm{amt}_{2} \mathrm{TSTQ}_{2}{ }^{1-2} \rightarrow \mathrm{mtTSTQ}_{2}{ }^{2} \rightarrow$ $\mathrm{amhQ}_{2}{ }^{3}$.

\section{Lời cảm ơn}

Nghiên cứu này được tài trợ bởi đề tài KC0902/16-20 (thuộc chương trình KC09/16-20 của Bộ Khoa học và Công nghệ) và đề tài $\mathrm{CA} \cdot 17.10 \mathrm{~A}$ (do Trung tâm Hỗ trợ Nghiên cứu Châu Á và Quỹ Giáo dục Cao học Hàn Quốc tài trợ). 


\section{Tài liệu tham khảo}

[1] Trần Nghi, Ngô Quang Toàn, Đặc điểm các chu kỳ trầm tích và lịch sữ tiến hóa địa chất Đệ tứ đồng bằng Sông Hồng, Tạp chí địa chất A (206207) (1991) 65-69.

[2] Trần Nghi, Trầm tích học (tái bản), Nhà xuất bản Đại học Quốc gia Hà Nội, Hà Nội, 2012.

[3] Trần Nghi, Trần Thị Thanh Nhàn, Trần Ngọc Diễn, Đinh Xuân Thành, Trần Thị Dung, Nguyễn Thị Phương Thảo, Trần Xuân Trường, Đỗ Mạnh Tuân, Diễn biến bồi tụ - xói lở bờ biển Thái Bình-Nam Định từ Holocen muộn đến nay trong mối quan hệ với tiến hóa các thùy châu thổ và lịch sử sông Sò, Tạp chí Khoa học, ĐHQGHN 34 (4) (2018). https://doi.org/10.25073/2588-1094/vnuees.4346

[4] Trần Nghi, Nguyễn Thị Tuyến, Đinh Xuân Thành, Nguyễn Đình Nguyên, Trần Thị Thanh Nhàn, Nguyễn Đình Thái, Nguyễn Thị Huyền Trang, Lê Viết Chuẩn, Nguyễn Hoàng Long, Đặc điểm tướng đá - cổ địa lý Pleistocen muộn - Holocen khu vực cửa sông $\mathrm{Ba}$ Lạt, Tạp chí Khoa học và Công nghệ Biển 17 (1) (2017) 23-34. https://doi.org/ 10.15625/1859-3097/17/1/8476

[5] Trần Nghi, Nguyễn Thị Tuyến, Đinh Xuân Thành, Nguyễn Đình Nguyên, Trần Thị Thanh Nhàn, Nguyễn Đình Thái, Nguyễn Thị Huyền Trang. Đường bờ cổ và ranh giới chéo các miền hệ thống trầm tích Pleistocen muộn - Holocen khu vực Bắc bộ và Bắc trung bộ. Tạp chí Địa chất $\mathrm{A}$ (358) (2016) 1-13.

[6] Vũ Cao Minh, Nguyễn Khắc Nghĩa, Nguyễn Huy Thịnh, Biến động cửa $\mathrm{Ba}$ Lạt, cửa Hà Lạn trong thời kỳ cận đại và ảnh hưởng của chúng tới diễn biến bồi tụ xói lở khu vực Hải Hậu - Nam Định. Tạp chí KH\&CN Thủy lợi Viện KHTLVN 3(13) (2013) 32 - 41.

[7] Doãn Đình Lâm, Tiến hóa trầm tích Holocen châu thổ Sông Hồng, Luận án tiến sĩ địa chất, ĐHQGHN, 2003.

[8] Tran Nghi, Mai Trong Nhuan, Chu Van Ngoi, Nguyen Van Dai, Dinh Dinh Xuan Thanh, Nguyen Dinh Nguyen, Nguyen Thanh Lan, Dam Quang
Minh, Ngo Quang Toan, GIS and image analysis to study the process of late Holocene sedimentary evolution in Balat River Mouth, Vietnam, Geoinformatics 14(1) (2003) 43-48.

[9] Tran Nghi, Mai Trong Nhuan, Chu Van Ngoi, P. Hoekstra, Utrecht, TJ. Van Weering, J.H. Van Denbergh, Dinh Xuan Thanh, Nguyen Dinh Nguyen, Vu Van Phai, Holocene sedimentary evolution, geodynamic and anthropogenic control of the Balat river mouth formation (Red Riverdelta, northern Vietnam), Z. geol. Wiss., Berlin 30, 3 (2002) 157-172.

[10] Vũ Quang Lân, Các mặt cắt địa chất chủ yếu của hệ tầng Hải Hưng vùng đồng bằng Sông Hồng. Tạp chí địa chất A (251) (1999) 9-13.

[11] Nguyễn Quang Miên, Lê Khánh Phồn, Some results of $\mathrm{C} 14$ dating in investigation on Quaternary geology and geomorphology in Nam Định - Ninh Bình area, Việt Nam. Tạp chí địa chất B (15) (2000) 106-109.

[12] Vũ Nhật Thắng, Phạm Đình Xin, Địa chất và Khoáng sản vùng Thái Bình - Nam Định (giới thiệu kết quả đo vẽ $B D Đ C$ và TNKS tỉ lệ $1 / 50.000$ nhóm tờ Thái Bình - Nam Định, 1997.

[13] Trần Đức Thạnh, Nguyễn Hữu Cử, Nguyễn Đức Cự, và nnk, Tình trạng và nguyên nhân xói lở, bồi tụ ven bờ châu thổ sông Hồng, Tuyển tập Tài nguyên và Môi trường biển. Tập III, Nhà xuất bản Khoa học và Kỹ thuật, Hà Nội, 2000.

[14] Trần Đức Thạnh, Đinh Văn Huy, Trần Đình Lân, Đặc điểm phát triển của vùng đất bồi ngập triều ven bờ châu thổ Sông Hồng. Tạp chí Các Khoa học về Trái đất 1 (18) (1996) 50-60.

[15] Ngô Quang Toàn, Đặc điểm trầm tích và lịch sử phát triển các thành tạo Đệ tứ ở phần đông bắc đồng bằng Sông Hồng, Luận án TS Khoa học Địa lí Địa chất; Đại học Tổng hợp Hà Nội, 1995.

[16] Trần Nghi, Đinh Xuân Thành và nnk, Quá trình tích tụ trầm tích Đệ tứ của đáy Sông Hồng trong mối quan hệ với hoạt động nhân sinh, Tuyển tập báo cáo hội thảo khoa học đánh giá tác động của quá trình xói mòn tại lưu vực Sông Hồng, Hà Nội, (2000) 124-151. 